\title{
Cerebrospinal Fluid Protein Level and Nerve Conduction Study as Short-Term Prognostic Marker of Guillain Barré Syndrome
}

\author{
KAMAL MM ${ }^{1}$, HABIB M ${ }^{2}$, ISLAM MR ${ }^{3}$, GHOSE SK$^{4}$, AHMED KGU $^{5}, \mathrm{CHOWDHURY} \mathrm{AH}^{6}$, \\ SHAHA K ${ }^{7}$, AMIN R $^{8}$, SINA H ${ }^{9}$, DHAR K ${ }^{10}$
}

\begin{abstract}
:
Background: Guillain Barré Syndrome (GBS) diagnosis is based on a combination of clinical features, Nerve conduction studies (NCS) and analysis of the cerebrospinal fluid (CSF) which eventually assist in monitoring disease progression as well as the efficacy of immunotherapy. The main objective of this study was to determine the relation of CSF protein level and nerve conduction study with short-term prognosis of GBS patients. Methods: This observational study was carried out in the Department of Neurology and Medicine, Dhaka Medical College Hospital, Dhaka during the period August, 2017 to July, 2018. Total 50 patients suffering from GBS were enrolled in this study. Lumber puncture (LP) and NCS were done at day 10 of symptom onset. Results: In this study majority (87.5\%) of the patients had GBS Disability score $<3$ in demyelinating and $16(47.1 \%)$ in axonal on day 90 . Three fourth (75.0\%) patients EGRIS score was ${ }^{33}$ in demyelinating and $34(100.0 \%)$ in axonal and mEGOS it was revealed that more than two third (68.8\%) patients mEGOS score was ${ }^{3} 6$ in Demyelinating and $33(97.1 \%)$ in axonal. More than three fourth (76.0\%) patients ${ }^{3} 6$ mEGOS score in CSF protein $<100$ (mg/dl) and 25(100.0\%) in CSF protein ${ }^{3} 100$ (mg/dl). Multiple logistic regression analysis showing a subject with axonal GBS had 1.579 (95.0\% C.I 1.717 to 3.475), CSF Protein had 1.013 (95.0\% C.I. 1.001 to 1.026) (PÂ0.05\%). Conclusion: CSF analysis for protein and NCS examination appeared as the essential short term predictors in evaluating diagnostic accuracy and prognostic determinant of GBS early.
\end{abstract}

Keywords: NCS, CSF Protein, GBS disability score, EGRIS, mEGOS

Introduction:

Guillain-Barré syndrome (GBS) is a postinfectious immune-mediated peripheral neuropathy characterised by rapidly progressive symmetrical weakness and sensory loss usually followed by slow clinical recovery with heterogeneous severity of neurological deficits and prognosis ${ }^{1}$. It is currently the most frequent cause of acute flaccid paralysis worldwide and constitutes one of the serious emergencies in neurology $2,3,4$. Statistical analyses reported the incidence of GBS in Western countries, mostly from Europe and North America, ranges from 0.89 to 1.89 cases per 100,000 populations per year ${ }^{4,5}$. GBS is typically triggered by antecedent infections presented as symptoms of upper respiratory tract infection or diarrhoea. Campylobacter jejuni is blamed for at least one-third of these infections, cytomegalovirus infections being the second most common ${ }^{6}$.

Autoimmune response is the cardinal step in the development of GBS. There is a molecular mimicry

1. Dr. Mohammad Mostafa Kamal, Resident (Neurology), DMCH, Dhaka

2. Dr. Mansur Habib, Professor (Retd.), Dept. of Neurology, DMCH, Dhaka

3. Prof. (Dr.) Md. Rafiqul Islam, Professor and Chairman, Dept. of Neurology, BSMMU, Dhaka.

4. Dr. Swapan Kumar Ghose, Associate Professor (Retd.) Dept. of Neurology, DMCH, Dhaka

5. Dr. Kazi Gias Uddin, Associate Professor, Dept. of Neurology, DMCH, Dhaka

6. Dr. Ahmed Hossain Chowdhury, Associate Professor, Dept. of Neurology, DMCH, Dhaka

7. Dr. Konol Shaha, Associate Professor, Dept. of Neurology, DMCH, Dhaka

8. Dr. Robed Amin, Associate Professor, Dept. of Neurology, DMCH, Dhaka

9. Dr. Hashmi Sina, Assistant Professor, Dept. of Neurology, DMCH, Dhaka

10. Dr. Kinghshuk Dhar, Resident (Neurology), DMCH, Dhaka. 
between the lipooligosaccharides of the infectious agents and the gangliosides in human, ultimately affecting the myelin-protein sheathing and the axons themselves to various degrees ${ }^{7}$. These lead to segmental demyelination and axonal degeneration as well as infiltration of macrophages, lymphocytes and mast cells in the endoneurium of nerves in the peripheral nervous system which are found in nerve biopsy ${ }^{8}$. Nerve conduction studies (NCS) are the fundamental investigations to confirm the diagnosis and to assess the severity of the disease ${ }^{9}$.

A new thought has been proposed recently and there many ongoing researches regarding the role of CSF studies as a prognostic marker of GBS. As GBS affects the peripheral nervous system, CSF is a potential source for biomarkers, since the CSF compartment is in close contact with the proximal nerve roots, where biochemical changes related to the disease are likely to be reflected ${ }^{10}$. Therefore the altered protein content of CSF due to various cerebrospinal fluid biomarkers, such as albumin, myelin basic protein, axonal damage markers (neurofilaments, tau and anti-ganglioside antibodies), glial and neuronal markers (neuron specific enolase, 14-3-3 proteins, S100B and hypocretin-1) is thought to mirror the damage within the tissue of the nervous system ${ }^{11}$. Moreover the dysfunction of B-CSF-B and BNB damage results in an alteration of CSF flow rate with influx of serum proteins into the CSF resulting in modulation of the protein content in CSF. Also the intra-thecal synthesis of proteins contributes to the changes of protein content in CSF. All these have been proposed the CSF protein could play a role as a marker for disease process, prognostic accuracy and treatment response ${ }^{10,11}$. In addition, electrophysiological studies on GBS patients have highlighted the prognostic value of early motor conduction studies ${ }^{12}$. Many studies regarding the role of CSF protein as a short-term prognostic marker have been conducted worldwide but no similar studies have been found in Bangladesh. Keeping the importance of the topic in mind the study has been designed to find out the role of CSF protein and motor NCS study in GBS.

\section{Methods:}

This study was carried out in the department of neurology, Dhaka Medical college hospital. A total of about 50 patients were included in the study following admission in department of neurology. A written informed consent was collected from each patient and interview has been taken by the researcher himself and verified by a consultant neurologist. A semi-structured questionnaire had been made consisting demographic profile, clinical presentation and comorbid disease. A special written consent was taken for lumbar puncture and with all aseptic precautions lumber puncture was done on day 10 of symptom onset. Following collection of CSF, sample was sent for study to the biochemistry laboratory of BSMMU. CSF protein estimation by using ultraviolet spectrophotometric method with a Atellica $\mathrm{CH}$ analyzer, Siemens, Germany and level of $45 \mathrm{mg} / \mathrm{dl}$ was used as upper cutoff value. Patients were divided into two groups according to the presence of amount of protein. In addition, Nerve Conduction Studies of cross limb were done at day 10 and type of GBS was stratified into demyelinating and axonal group based upon the criteria suggested by Albers and Kelly by using Nihon Cohden Neuropack 2 system (Nihon Cohden Corp, Tokyo, Japan) maintaing the skin temperature at 32-34úc. Assessment of prognosis was done at day 10 of onset of symptom using EGRIS and mEGOS score and GBS disability score at admission and day 90 of symptom onset. Patients whose condition improved were discharged from hospital. Patients address and telephone number taken and contacted and advised for followed up at 90 days in Neurology Specialized Clinic, DMCH.

\section{Results:}

In this study, almost three fourth $(76.0 \%)$ patients belong to age 18-25 years and almost three fourth $(72.0 \%)$ patients were male and $14(28.0 \%)$ were female. By NCS findings, it was observed that more than two third (68.0\%) patients had axonal and $16(32.0 \%)$ demyelinating. 
Table I shows that more than two third $(68.0 \%)$ patients had axonal and $16(32.0 \%)$ in demyelinating.

\section{Table-I}

Distribution of the study patients by NCS findings $(n=50)$

\begin{tabular}{lcc}
\hline NCS findings & Number of patients & Percentage \\
\hline Axonal & 34 & 68.0 \\
Demyelinating & 16 & 32.0 \\
\hline
\end{tabular}

Table II shows that more than half $(52.9 \%)$ of the patients had GBS Disability score $>3$ in axonal and $2(12.5 \%)$ in demyelinating at day 90 . The difference was statistically significant $(p<0.05)$ between two groups.

Table III shows that three fourth $(75.0 \%)$ patients EGRIS score was $\geq 3$ in demyelinating and $34(100.0 \%)$ in axonal. The difference was statistically significant $(p<0.05)$ between two groups.

Table IV shows that more than two third $(68.8 \%)$ patients $m E G O S$ score was $\geq 6$ in Demyelinating and $33(97.1 \%)$ in axonal. The difference was statistically significant $(p<0.05)$ between two groups.

Table $V$ shows that more than half $(61.8 \%)$ patients belonged to CSF protein $\geq 100(\mathrm{mg} / \mathrm{dl})$ in axonal and $4(25 \%)$ in demyelinating. The difference was statistically significant $(p<0.05)$ between two groups.
Table VI shows that more than half ( $56.0 \%$ ) patients had GBS disability score $>3$ on day 90 in CSF protein $\geq 100(\mathrm{mg} / \mathrm{dl}), 6(24.0 \%)$ in CSF protein $<100$ $(\mathrm{mg} / \mathrm{dl})$. The difference was statistically significant (pÂ0.05) between two groups.

Table VII shows that all (100.0\%) patients had EGRIS score $\geq 3$ in CSF protein $\geq 100(\mathrm{mg} / \mathrm{dl})$ and $21(84.0 \%)$ in CSF protein $<100(\mathrm{mg} / \mathrm{dl})$. The difference was statistically significant ( $\mathrm{pÂ} 0.05)$ between two groups.

Table VIII shows that more than three fourth $(76.0 \%)$ patients had mEGOS score $\geq 6$ in CSF protein $<100(\mathrm{mg} / \mathrm{dl})$ and $25(100.0 \%)$ in CSF protein $\geq 100(\mathrm{mg} / \mathrm{dl})$. The difference was statistically significant $(p<0.05)$ between two groups.

Table IX shows that a subject with axonal GBS had $1.579(95.0 \%$ C.I 1.717 to 3.475$)$, CSF Protein had 1.013 (95.0\% C.I. 1.001 to 1.026), EGRIS had 0.659 (95.0\% C.I. 0.355 to 1.224$)$ and mEGOS had $1.172(95.0 \%$ C.I. 0.415 to 3.31$)$ times increase in odds, where only axonal GBS and CSF protein were statistically significant $(P<0.05 \%)$.

Table X shows ROC curves based GBS Disability score on day 90 , EGRIS and mEGOS which had area under curve (AUC) 0.910, 0.606 and 0.836 . ROC curve was constructed by using GBS Disability score on day 90, EGRIS and mEGOS,

Table-II

Comparison of NCS findings with GBS Disability score at day 90 of admission of the study patients $(n=50)$

\begin{tabular}{lcccccc}
\hline GBS Disability & \multicolumn{2}{c}{90 Demyelinating $(n=16)$} & & \multicolumn{2}{c}{ Axonal $(n=34)$} & P value \\
\cline { 2 - 3 } \cline { 5 - 6 } score at day & $n$ & $\%$ & & $n$ & $\%$ & \\
\hline$<3$ & 14 & 87.5 & & 16 & 47.1 & $0.001^{\text {s }}$ \\
$\geq 3$ & 2 & 12.5 & & 18 & 52.9 & \\
\hline
\end{tabular}

Table-III

Comparison of NCS findings with EGRIS score at day 10 of the study patients $(n=50)$

\begin{tabular}{lcccccc}
\hline EGRIS score 10 & \multicolumn{2}{c}{ Demyelinating $(n=16)$} & & \multicolumn{2}{c}{ Axonal $(n=34)$} & P value \\
\cline { 2 - 3 } \cline { 5 - 6 } at day & $n$ & & & $n$ & 0.0 & $0.002^{s}$ \\
\hline$<3$ & 4 & 25.0 & & 0 & 100.0 & \\
\hline 3 & 12 & 75.0 & & 34 & 10.0 \\
\hline
\end{tabular}


Table-IV

Comparison of NCS findings with mEGOS score at day 10 of the study patients $(n=50)$

\begin{tabular}{lcccccc}
\hline mEGOS score & \multicolumn{2}{c}{ Demyelinating $(\mathrm{n}=16)$} & & \multicolumn{2}{c}{ Axonal $(\mathrm{n}=34)$} & P value \\
\cline { 2 - 4 } at day 10 & $\mathrm{n}$ & $\%$ & & $\mathrm{n}$ & $\%$ & \\
\hline$<6$ & 5 & 31.3 & 1 & 2.9 & $0.001^{\mathrm{s}}$ \\
$\geq 6$ & 11 & 68.8 & 33 & 97.1 & \\
\hline
\end{tabular}

Table-V

Comparison of NCS findings with CSF protein of the study patients $(n=50)$

\begin{tabular}{|c|c|c|c|c|c|}
\hline \multirow{2}{*}{$\begin{array}{l}\text { CSF protein } \\
(\mathrm{mg} / \mathrm{dl})\end{array}$} & \multicolumn{2}{|c|}{ Demyelinating $(n=16)$} & \multicolumn{2}{|c|}{ Axonal $(n=34)$} & \multirow[t]{2}{*}{$P$ value } \\
\hline & $\mathrm{n}$ & $\%$ & $\mathrm{n}$ & $\%$ & \\
\hline$<100$ & 12 & 75.0 & 13 & 38.2 & \\
\hline$\geq 100$ & 4 & 25.0 & 21 & 61.8 & \\
\hline Mean $\pm S D$ & 112.41 & \pm 33.32 & 139.56 & \pm 30.25 & $0.008^{\mathrm{s}}$ \\
\hline Ranges(min-max) & 48 & -255 & 70 & -273 & \\
\hline
\end{tabular}

Table VI

Comparison of CSF protein with GBS Disability score at day 90 of admission of the study patients $(n=50)$

\begin{tabular}{lcccccc}
\hline GBS disability & \multicolumn{2}{c}{$<100(\mathrm{mg} / \mathrm{dl})(\mathrm{n}=25)$} & & \multicolumn{2}{c}{$\geq 100(\mathrm{mg} / \mathrm{dl})(\mathrm{n}=25)$} & P value \\
\cline { 2 - 3 } score at day 90 & $\mathrm{n}$ & $\%$ & & $\mathrm{n}$ & $\%$ & \\
\hline$<3$ & 19 & 76.0 & 11 & 44.0 & $0.021^{\mathrm{s}}$ \\
$\geq 3$ & 6 & 24.0 & & 14 & 56.0 & \\
\hline
\end{tabular}

Table-VII

Comparison of CSF protein with EGRIS score at day 10 of the study patients ( $n=50)$

\begin{tabular}{lcccccc}
\hline EGRIS score & \multicolumn{2}{c}{$<100(\mathrm{mg} / \mathrm{dl})(\mathrm{n}=25)$} & & \multicolumn{2}{c}{$\geq 100(\mathrm{mg} / \mathrm{dl})(\mathrm{n}=25)$} & P value \\
\cline { 2 - 3 } at day 10 & $\mathrm{n}$ & $\%$ & & $\mathrm{n}$ & $\%$ & \\
\hline$<3$ & 4 & 16.0 & & 0 & 0.0 & $0.037^{\mathrm{s}}$ \\
$\geq 3$ & 21 & 84.0 & & 25 & 100.0 & \\
\hline
\end{tabular}

Table-VIII

Comparison of CSF protein with mEGOS score at day 10 of the study patients $(n=50)$

\begin{tabular}{lcccccc}
\hline mEGOS score & \multicolumn{2}{c}{$<100(\mathrm{mg} / \mathrm{dl})(\mathrm{n}=25)$} & & \multicolumn{2}{c}{$\geq 100(\mathrm{mg} / \mathrm{dl})(\mathrm{n}=25)$} & P value \\
\cline { 2 - 3 } at day 10 & $\mathrm{n}$ & $\%$ & & $\mathrm{n}$ & $\%$ & \\
\hline$<6$ & 6 & 24.0 & & 0 & 0.0 & $0.009^{\mathrm{s}}$ \\
$\geq 6$ & 19 & 76.0 & & 25 & 100.0 & \\
\hline
\end{tabular}


Table-IX

Multiple logistic regression analysis showing the effect of independent variables on dependent variable

\begin{tabular}{lcccc}
\hline & OR & \multicolumn{2}{c}{$95 \%$ C.I. } & P value \\
\cline { 3 - 4 } & & Lower & Upper & \\
\hline Axonal GBS & 1.579 & 1.717 & 3.475 & $0.021^{\mathrm{s}}$ \\
CSF protein & 1.013 & 1.001 & 1.026 & $0.038^{\mathrm{s}}$ \\
EGRIS & 0.659 & 0.355 & 1.224 & $0.187^{\text {ns }}$ \\
mEGOS & 1.172 & 0.415 & 3.31 & $0.764^{\text {ns }}$ \\
\hline
\end{tabular}

Table-X

Receiver-operator characteristic (ROC) curve of GBS disability score on day 90 , EGRIS and mEGOS score

\begin{tabular}{lcccccc}
\hline & $\begin{array}{l}\text { Cut of } \\
\text { value }\end{array}$ & Sensitivity & Specificity & AUC & \multicolumn{2}{c}{$\begin{array}{c}95 \% \text { Confidence } \\
\text { interval }(\mathrm{Cl})\end{array}$} \\
\cline { 3 - 7 } & & & & & $\begin{array}{l}\text { Lower } \\
\text { bound }\end{array}$ & $\begin{array}{c}\text { Upper } \\
\text { bound }\end{array}$ \\
\hline $\begin{array}{l}\text { GBS Disability } \\
\text { score on day } 90\end{array}$ & 2.50 & 58.8 & 100.0 & 0.910 & 0.830 & 0.990 \\
$\begin{array}{l}\text { EGRIS } \\
\text { mEGOS }\end{array}$ & 3.50 & 91.2 & 50.0 & 0.606 & 0.398 & 0.813 \\
\hline
\end{tabular}

which gave a cut off value $2.50,3.50$ and 6.50 with $58.8 \%, 91.2 \%$ and $67.6 \%$ sensitivity and $100.0 \%$,

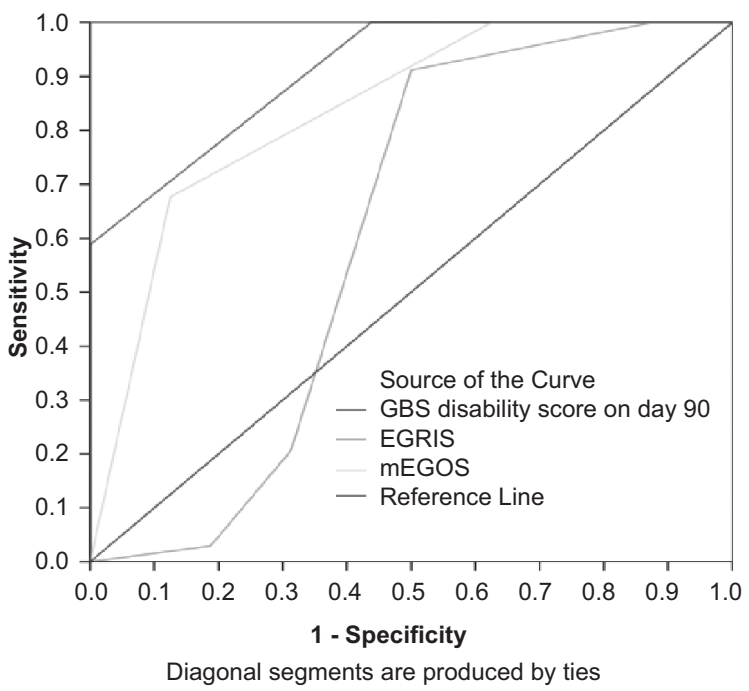

Fig.-1: Receiver-operator characteristic (ROC) curve showing area under curve(AUC) of GBS Disability score on day 90, EGRIS and mEGOS score.
$50.0 \%$ and $87.5 \%$ specificity respectively for prediction of GBS patients.

\section{Discussion:}

In this study age distribution was found mostly in young age group because Bangladesh is a developing country, so there is infection specially campylobacter jejuni infection affect may be more in this age group. In our population axonal variety is most prevalent and different findings from western and European countries may be due to more prevalence of c.jejuni infection in our population due to cultural, environmental \& climate factors. Regarding NCS findings all short term prognostic score i.e. GBS disability score, EGRIS score and mEGOS score showed that axonal variety was associated with high score and worse prognosis. Regarding CSF protein all short term prognostic marker also showed that increased protein was associated with high score and worse prognosis. According to ROC curve, it was shown that all the three scores are useable for the prediction of outcome of GBS but mEGOS score 
is more acceptable because its sensitivity and specificity both is in acceptable range than other two score. In multiple logistic regression analysis showed that axonal GBS and increased CSF protein was independent prognostic factor of Guillain Barre' Syndrome patients.

\section{Conclusion:}

Cerebrospinal fluid analysis for protein and Nerve conduction studies appeared as the essential short term predictors in evaluating diagnostic accuracy and the prognostic determinant of GBS early. However, the role of EGRIS score, mEGOS score and GBS disability score in categorization of different variants of GBS are also encouraging for formulating the futures strategies based on the unique scoring as revealed in this study. The data generated in this research will serve as baseline information in order to practice in neurological centers for assessment of the clinical stage and management of the critically ill crippling GBS patients. It can be said that the present study presents the role of increased CSF protein and Nerve conduction studies as prognostic markers of Guillain-Barré syndrome.

\section{References:}

1. Van Koningsveld R, Steyerberg EW, Hughes RA, Swan AV, van Doorn PA, Jacobs BC. A clinical prognostic scoring system for GuillainBarré syndrome. The Lancet Neurology. 2007 Jul 1;6(7):589-94.

2. Shahrizaila N, Yuki N. Peripheral neuropathies: Clinical prognostic scales in Guillain-Barré syndrome. Nature Reviews Neurology. 2011 Jul;7(7):362.

3. Willison HJ, Jacobs BC, van Doorn PA. Guillain-barre syndrome. The Lancet. 2016 Aug 13;388(10045):717-27.

4. Yuki N, Hartung HP. Guillain-Barré syndrome. New England Journal of Medicine. 2012 Jun 14;366(24):2294-304.

5. Poropatich KO, Walker CL, Black RE. Quantifying the association between
Campylobacter infection and Guillain-Barré syndrome: a systematic review. Journal of health, population, and nutrition. 2010 Dec;28(6):545.

6. Sejvar JJ, Baughman AL, Wise M, Morgan OW. Population incidence of Guillain-Barré syndrome: a systematic review and metaanalysis. Neuroepidemiology. 2011;36(2):12333.

7. Van Den Berg B, Walgaard C, Drenthen J, Fokke C, Jacobs BC, Van Doorn PA. GuillainBarré syndrome: pathogenesis, diagnosis, treatment and prognosis. Nature Reviews Neurology. 2014 Aug;10(8):469.

8. Hughes RA, Cornblath DR. Guillain-barre syndrome. The Lancet. 2005 Nov 5;366(9497):1653-66.

9. Kerasnoudis A, Pitarokoili K, Behrendt V, Gold $\mathrm{R}$, Yoon MS. Increased cerebrospinal fluid protein and motor conduction studies as prognostic markers of outcome and nerve ultrasound changes in Guillain-Barré syndrome. Journal of the neurological sciences. 2014 May 15;340(1-2):37-43.

10. Brettschneider J, Petzold $A$, Süssmuth $S$, Tumani H. Cerebrospinal fluid biomarkers in Guillain-Barré syndrome-Where do we stand?. Journal of neurology. 2009 Jan 1;256(1):3-12.

11. Wang $Y$, Sun S, Zhu J, Cui L, Zhang HL. Biomarkers of Guillain-Barre syndrome: some recent progress, more still to be explored. Mediators of inflammation. 2015;2015.

12. Cornblath DR, Mellits ED, Griffin JW, McKhann GM, Albers JW, Miller RG, Feasby TE, Quaskey SA, Guillain Barré Syndrome Study Group. Motor conduction studies in Guillain Barré syndrome: description and prognostic value. Annals of neurology. 1988 Apr;23(4):354-9. 